\title{
STRENGTH TRAINING AND ANABOLIC STEROID DO NOT AFFECT MUSCLE CAPILLARIZATION OF MIDDLE-AGED RATS
}

\author{
TREINAMENTO DE FORÇA EESTEROIDE ANABOLIZANTENÃO AFETAM A CAPILARIZAÇÃO \\ MUSCULARDERATOSDEMEIA-IDADE \\ ENTRENAMIENTO DE FUERZA Y ESTEROIDE ANABOLIZANTE NO AFECTAN LA CAPILARIDAD \\ MUSCULARDERATAS DEMEDIANAEDAD
}

\begin{abstract}
Walter Krause Neto'
(Profissional de Educação Física)

Eliane Florencio Gama

(Fisioterapeuta)

1. Universidade São Judas Tadeu, Departamento de Educação Física, Laboratório de Estudos Morfoquantitativos e Imunohistoquímica, São Paulo, SP, Brasil.
\end{abstract}

\section{Correspondência:}

Walter Krause Neto. Universidade São Judas Tadeu, Unidade Mooca. R. Taquari, 546, Mooca, São Paulo, SP, Brasil. 03166-000.

wild_krause@hotmail.com

\begin{abstract}
Introduction: It is generally accepted that the capillary network decreases with advancing age. The combined effect of resistance training (RT) and testosterone still needs to be elucidated. Objective: This study aimed to measure capillary profile of different skeletal muscles of middle-aged rats undergoing RT and administration of exogenous testosterone. Methods: Wistar rats were divided into five experimental groups: control with 13-month-old rats (SC), control with 16-month-old rats (SE), aged rats + anabolic agent (SA), aged rats + RT $(T)$, and aged rats $+R T+$ anabolic agent (TA). Results: For soleus, the SE group presented a decrease in the percentage of capillaries in comparison to SC group. SA, T, and TA groups had increased capillary volume in comparison to SC. As for the extensor digitorum longus (EDL), SA, T, and TA groups demonstrated lower capillary volume and numeric density in comparison to SC and SE. The EDL of the T and TA groups presented 70\% less capillaries than soleus. The numerical and volumetric density and capillary ratio by muscle fiber were not statistically altered by any intervention. The cross-sectional area (CSA) of the soleus of the SA, T and TA groups was statistically different from SC group. The soleus CSA was greater in the TA and T groups than in the SC, SE and SA groups, and the EDL CSA was greater in the TA compared to all other groups. The TA group had greater values than the SE, SA, and T groups. Conclusion: The type of intervention used did not affect any variables measured in the capillary profile. However, the use of anabolic steroid and/or RT showed a tendency to decrease the density of capillaries in the EDL.
\end{abstract}

Keywords: vasomotor system; resistance training; rats, inbred strains; animals; muscle, skeletal.

\section{RESUMO}

Introdução: Em geral, se aceita que a rede capilar diminui com o avanço da idade. O efeito combinado de treinamento resistido (TR) e testosterona ainda precisa ser elucidado. Objetivo: Este estudo visou medir o perfil capilar de diferentes músculos esqueléticos em ratos de meia-idade submetidos a TRe administração de testosterona exógena. Métodos: Ratos Wistar foram divididos em cinco grupos experimentais: controle com ratos de 13 meses de idade (SC), controle com ratos de 16 meses de idade (SE), ratos idosos + anabolizante (SA), ratos idosos + TR (T) e ratos idosos + TR + anabolizante (TA). Resultados: Para o músculo sóleo, o grupo SE apresentou decréscimo do percentual de capilares em comparação como grupo SC. Os grupos SA, Te TA tiveram aumento do volume de capilares em comparação com o SC. Por outro lado, para o músculo extensor longo dos dedos (ELD), os grupos SA, Te TA demonstraram menor volume e densidade numérica de capilares, em comparação com SC eSE. O músculo ELD dos grupos Te TA apresentou 70\% menos capilares do que o sóleo. A densidade numérica e volumétrica e a razão de capilares por fibra muscular não foram estatisticamente alteradas por nenhuma das intervenções. A área de corte transversal (ACT) do músculo sóleo dos grupos SA, Te TA foi estatisticamente diferente do grupo SC. A ACT do sóleo foi maior nos grupos TA e T do que nos grupos SC, SE e SA e a ACT do ELD foi maior no grupo TA comparada com todos os outros grupos. O grupo TA teve valores maiores do que os grupos SE, SA e T. Conclusão: O tipo de intervenção usada não afetou qualquer variável mensurada do perfil capilar. Entretanto, o uso de esteroide anabolizante e/ou TR mostrou tendência de diminuir a densidade de capilares no músculo ELD.

Descritores: sistema vasomotor; treinamento de resistência; ratos endogâmicos; animais; músculo esquelético.

\section{RESUMEN}

Introducción: Se acepta en general que la red capilar disminuye con la edad. El efecto combinado de entrenamiento de resistencia (ER) y la testosterona todavía necesita ser aclarado. Objetivo: Este estudio tuvo como objetivo medir el perfil capilar de diferentes músculos esqueléticos de ratas de mediana edad sometidas a ER y la administración de testosterona exógena. Métodos: Se dividieron ratas Wistar en cinco grupos: control con ratas de 13 meses de edad (SC), control con ratas de 16 meses de edad (SE), ratas de edad avanzada + anabolizantes (SA), ratas de edad avanzada + +ER (T) y ratas de edad avanzada + ER + anabolizante (TA). Resultados: Para el músculo sóleo, el grupo SE mostró una disminución en el porcentaje de capilares en comparación con el grupo SC. Los grupos SA, Ty TA presentaron aumento del volumen de capilares en comparación con el SC. Por otro lado, para el músculo extensor largo de los dedos (ELD), los grupos SA, Ty TA mostraron menor volumen y menor número de capilares en comparación con los 
grupo SC y SE. El músculo ELD de los grupos Ty TA presentó 70\% menos capilares que el sóleo. La densidad numérica y volumétrica y la proporción de capilares por fibra muscular no se alteraron significativamente por ninguna de las intervenciones. El área de sección transversal (AST) del músculo sóleo de los grupos SA, Ty TA fue estadísticamente diferente que el grupo SC. EI AST del sóleo fue mayor en los grupos TA y T que en los grupos SC, SE y SA, y el AST del ELD fue mayor en el grupo TA en comparación con todos los demás grupos. El grupo TA tuvo valores más altos que los grupos SE, SA y T. Conclusión: El tipo de intervención utilizada no afecta a ninguna variable medida del perfil capilar. Sin embargo, el uso de esteroides anabolizantes y/o ER tendió a reducir la densidad capilar en el músculo ELD.

Descriptores: sistema vasomotor; entrenamiento de resistencia; ratas consanguíneas; animales; músculo esquelético.

\section{INTRODUCTION}

In general, it is accepted that capillary network declines during age advance. Despite conflicting results, some studies showed minimal reduction in the number of capillaries from muscles of elderly compared to young ${ }^{1}$. Even so, the amount of work proposing to analyze the aging effect on vascularity of different skeletal muscle types is small. Besides it, morphological analysis are frequently done comparing young and very old samples ${ }^{2,3}$. As known, many aging alterations might begin earlier than expected. Even so, middle-age measurements became necessary to understand when changes from aging process might actually begin.

Micro environmental failure to produce supportive structures, such as capillary vessels, may account for a limited capacity of skeletal muscle during physical stress. Reports exist about alterations on capillarization of skeletal muscle during endurance training, electrical stimulation, and hormonal or drug manipulation ${ }^{4}$. In human biopsy studies, capillarization has been reported to be maintained or reduced with increasing age $^{3,5}$. Exercise, such as aerobic training, can induce an increase in blood capillaries volume ${ }^{4}$. It translates into skeletal muscles more resistant to fatigue, thus enhancing muscle-buffering capacity. This adaptation has been described for skeletal muscles rich in type I fibers, such as Soleus muscle. Despite this, little about the effect of resistance training (RT) on muscle capillary network is known, as well as, on other skeletal muscles types with different myofibers predominance.

Testosterone is a major anabolic hormone produced endogenously. In muscle fibers, testosterone is known to increase protein synthesis, resistance capacity, strength and muscular size ${ }^{6}$. As recently mentioned, testosterone also increases the ratio of capillaries in rat's heart ${ }^{7}$. Nevertheless, there are few data about the effect of testosterone on skeletal muscle capillarity density. In addition, conjugated effect of RT and testosterone on these issues remain to be elucidated.

Thus, this study aimed to investigate the capillarity profile of different skeletal muscle types of middle-aged rats undergoing RT and administration of testosterone.

\section{MATERIALS AND METHODS}

This work was performed at the Laboratory of Morphoquantitative Studies and Immunohistochemistry (LMSI) of São Judas Tadeu University (protocol 015/2006). Twenty-eight middle-aged male Wistar rats (Rattus norvegicus, 13 months-age, $526.0 \pm 105.3 \mathrm{~g}$ ) were used from the animal house of the São Judas Tadeu University. During experimentation, animals were housed in boxes of polypropylene (three each), kept under controlled environmental conditions of temperature $\left(22^{\circ} \mathrm{C}\right)$ and lighting (12-hour cycle of light and 12 hours dark). For all groups, were provided reference commercial food for rats (2.0 g protein/ $\mathrm{kg}$ body weight) and water ad libitum. Wistar rats with 13-16 months of age is not necessarily old. However, compared with humans, at this age, animals lived about $54-66 \%$ of its life expectancy ${ }^{7}$. Therefore, at this age, many aging changes are already in progress. In addition, at this age, rats are passing from adult to aged status. Being so, an interesting age to study.

Animals were divided into five groups and subjected to procedures, as described: Group SC - 13 months-old sedentary animals used as initial control of procedures $(n=5)$; Group SE - 16 months-old sedentary animals used as sedentary final control of procedures $(n=6)$; Group SA - sedentary animals that received testosterone propionate from 13 to 16 months of age $(n=6)$; Group $T$ - animals that underwent RT protocol from 13 to 16 months of age $(n=5)$; and Group TA - animals that underwent RT and received testosterone propionate, from 13 to 16 months of age $(n=6)$.

\section{Resistance training protocol}

For RT protocol, we inverted the light-dark cycle of the animal's room, respecting it circadian rhythm (active period). RT was applied over a vertical ladder, made of wood, with iron steps. The height of the equipment (ladder) was $110 \mathrm{~cm}$, with inclination of $80^{\circ}$. On top, a plastic box was placed for accommodation of the animals during climbing intervals ${ }^{8}$.

The training program was based on the principle of overload, with number of repetitions and rest, closest to human RT models. The classification of muscle strength was based on the relationship between the overload used to perform certain exercise and body weight of the trained individual. Being so, repetition maximum (1RM) table for humans proposed by Heyward ${ }^{9}$ was adapted and applied for rodent RT. Proposedly, all animals were weighted and their loads adjusted once a week. For this purpose, a semi-analytical balance brand Gehaka BG 100 was used.

All animals performed a five days adaptation period prior to training. All rats climbed the ladder in order to reach a rest area at the top. This procedure was repeated for six consecutive occasions with 45 seconds interval without any overload. Animals from SC climbed the ladder once, five times per week, until euthanize. The SE and SA groups climbed the ladder once a day, five times per week, without any overload throughout the entire training protocol. This procedure was taken in order to provoke a similar, but inferior, stress felt by trained groups. T and TA climbed the ladder six times, 5x/week, during 16 weeks. Between each climb, rats rest 45 seconds at ladder top.

Perhaps sedentary lifestyle, rodent RT started with index rating "Good" (as reference to men), since it was in good health. The referential "Good" corresponds to $75 \%$ of animal's body weight and was applied to T and TA during the first 4 weeks of experimentation. From this point of training, and every two weeks, overload was increased for benchmark at 0.80, $0.90,1.00,1.10$ and 1.20. Training references were adjusted every week according to animal's body weight. Nevertheless, if it's body weight decreased, the last burden was maintained. For load adjustment, the following calculus was applied:

Example: Load / Body weight coefficient =

Adaptation to Experimental Models

Body weight $x$ coefficient $=$ Load

Ex: $500 \mathrm{~g} \times 0.75(\mathrm{Good})=375 \mathrm{~g}$ 
The PERINON ${ }^{\circledR}$ hormone (testosterone propionate, veterinary/ Perini laboratory in flask with $100 \mathrm{ml}$ vial containing $1 \mathrm{~g}$ of testosterone propionate and peanut oil qs $100 \mathrm{ml}$ ) was used here. The dose was calculated according to weight of the animals, on the same proportion that is used in humans. The prescribed dose for an adult weighting $70 \mathrm{~kg}$ is $200 \mathrm{mg}$ of testosterone propionate every three weeks ${ }^{7}$. Thus, a dose equal $3 \mathrm{mg} / \mathrm{kg}$ (body weight) of testosterone propionate was injected each time.

The administration of testosterone propionate was applied three times a week, for SA and TA, via intramuscular applications during the entire training period.

All animals were anesthesia with an intraperitoneal injection of thiopental (40mg/kg body weight, Sigma ${ }^{\circledR}$, USA). After euthanize, Soleus (SL) and Extensor digitorum longus (EDL) muscles were removed and prepared for light microscopy. These skeletal muscle were chosen because of it functional and morphological characteristics. Soleus muscle is classified as postural and predominantly constituted by slowtwitch myofibers. Inversely, EDL is a fast-twitch predominant muscle recruited during higher levels of physical activity. Recently, literature have shown that slow and fast-twitch muscle types (such these) might have different aging times and perhaps, different sarcopenia mechanisms ${ }^{10,11}$. An incision was made in the right hind paws of the animal to expose both muscles. Samples were randomly cut, and fragments fixed in 10\% buffered formalin. Afterword, material was dehydrated in increasing series of alcohols, diaphanized in xylene, embedded in paraffin, sectioned in slices of $7 \mu \mathrm{m}$ thick and stained with hematoxylin and eosin (HE) for analysis at light microscopy.

\section{Stereology and morphometric study}

Stereological method seeks the interpretation of three-dimensional structural arrangement, making possible a very efficiently quantitative analysis (density per volume, and surface area) ${ }^{12}$. To estimate volume density of capillaries ( $\mathrm{V} v[\mathrm{cap}]$ ) and myocytes ( $\mathrm{V} v[\mathrm{myo}]$ ), 15 photos corresponding to each muscle of each group were photographed under the light microscope with final magnification of 100x. Stereological analysis was performed using the Image J program. This program allowed us to count capillaries and myocytes on a points system. Further, we estimated numerical density of capillaries (Nv[cap]) by counting the number of capillaries per frame and dividing it by the number of frames used per muscle group. For last, the ratio of capillaries by muscle fibers (ratio[cap/ fib]) was applied. We divided relative number of capillaries per frame by total number of muscle fibers.

For morphometric study, 20 images were taken from each plate to analyze myofiber cross-sectional area (CSA). Measurements were made using image analysis program (AxioVision version 4.8) attached to a light microscope (Zeiss) with the 100-fold magnification.

\section{Statistical analysis}

For statistical analysis, data are presented as mean and standard deviation (mean \pm SD). ANOVA one-way (post hoc Tukey) was applied for data comparison between groups, with statistical differences set at $\mathrm{p} \leq 0.05$. For data management was used software SPSS version 21.0.

\section{RESULTS}

Table 1 demonstrated results for $\mathrm{V}$ [cap] between all groups selected per muscle type. For SL, SE presented fewer capillaries percentage than SC. SA, T and TA presented more capillaries in comparison to SC. Besides it, neither group showed statistical significance. $\mathrm{V}$ [myo] analysis, also did not present any group-by-group statically difference. For EDL, groups SA, T and TA demonstrated fewer VV[cap] than SC and SE. T and TA presented a trend to decrease $V v[c a p](p=0.059)$.
Figure 1 demonstrated analysis comparing both muscles results. EDL from T and TA presented 70\% less capillaries than SL. Both groups showed statistically difference $(T[p=0.000]$ and $T A[p=0.001])$.

Neither group-by-group comparison presented significant statistical difference for Nv[cap] (Table 2). For ratio [cap/fib] of SL, analysis of variance showed a between group statistical difference $(F=2,572, p<0.05)$. However, individual comparison did not demonstrate any mean full difference. Data are presented in Table 2.

Groups SA, T and TA presented larger SL CSA than SC $(p<0.05)$. $T$ and TA were larger than SE and SA $(p=0.00)$. Figure 2 shown groupby-group comparison.

For EDL, TA and T CSA were larger than SC $(p<0.05)$. TA was larger than, $S E, S A$ and $T(p=0.00)$. Figure 3 shown group-by-group comparison.

\section{DISCUSSION}

Despite conflicting results, some studies shown minimal reduction in the number of capillaries of skeletal muscles during age advancing ${ }^{1}$. Muscle capillarization must represent the potential to exchange gases, fuel and metabolites during exercise ${ }^{13}$. While the evidence for improvement of capillarity profile is already quite clear for aerobic exercise, it is not visible when dealing with RT ${ }^{1}$. Hepple and Mathieu-Costello ${ }^{14}$ quoted that beyond the limitations of longitudinal studies, methodologies of many studies might present several bias, as poor data quality and confounding interpretation. Being so, we measured capillarity profile of two different skeletal muscle types during early aging process, and through RT and exogenous testosterone administration. So far, we were able to show that capillarity profile did not change during early aging status, even when rats received both treatments. Nevertheless, Soleus muscle presented a minimal (not statically) increase in capillarity density over RT

Table 1. Comparison of capillary volume density (Vv[cap]) from Soleus (SL) and Extensor digitorum longus (EDL) muscles between groups sedentary control (SC), sedentary aged (SE), sedentary plus anabolic steroid (SA), trained (T) and trained plus anabolic steroid (TA).

\begin{tabular}{c|c|c|c|c}
\hline Muscle & Groups & Vv[cap] (\%) & F & P value \\
\hline \multirow{5}{*}{ SL } & SC & $0.9 \pm 1.5$ & & \\
& SE & $0.8 \pm 1.4$ & & \\
& SA & $1.0 \pm 1.6$ & 1.103 & 0.355 \\
& T & $1.2 \pm 1.6$ & & \\
\hline \multirow{5}{*}{ ELD } & TA & $1.2 \pm 1.8$ & & \\
& SC & $0.8 \pm 1.5$ & & \\
& SE & $0.8 \pm 1.2$ & & \multirow{2}{*}{0.059} \\
& SA & $0.7 \pm 1.2$ & 2.290 & \\
\hline
\end{tabular}

Values are presented as mean \pm standard deviation.

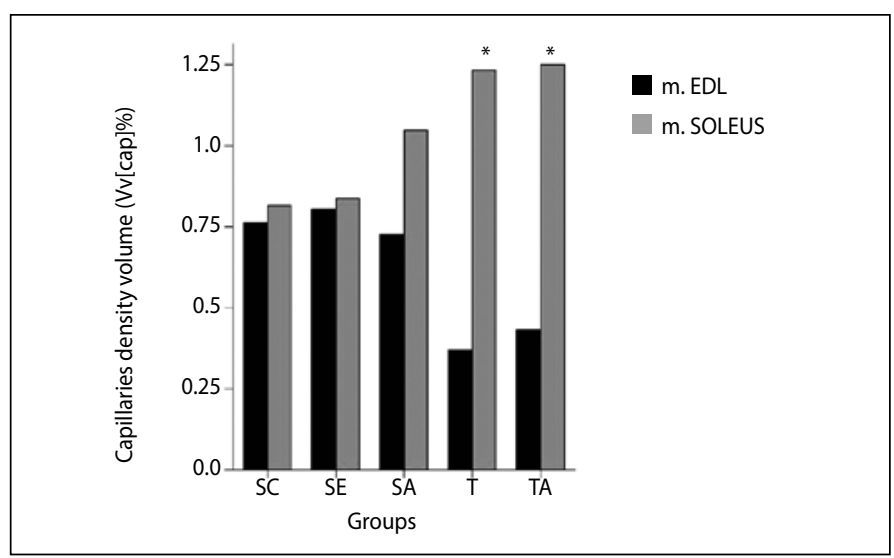

Figure 1. Percentage distribution of volume density occupied by capillaries ( $\mathrm{Vv}$ [cap]) between groups: Control (SC), Sedentary final (SE), Sedentary with Anabolic (SA), Trained (T) and trained with Anabolic (TA) between Soleus (SL) and Extensor digitorum longus (EDL). * Significant difference compared to SL for T and TA $(p=0.001)$. 
Table 2. Numerical density of capillaries (Nv[cap]) and capillary/fiber ratio (Ratio[cap/ fib]) of the groups SC, SE, SA, T and TA from Soleus (SL) and Extensor digitorum longus muscles (EDL).

\begin{tabular}{c|c|c|c|c}
\hline Groups & SL & & EDL & \\
\hline & Nv[cap] & Ratio[cap/fib] & Nv[cap] & Ratio[cap/fib] \\
\hline SC & $0.71 \pm 1.24$ & $0.015 \pm 0.03$ & $0.61 \pm 1.17$ & $0.012 \pm 0.02$ \\
\hline SE & $0.65 \pm 1.08$ & $0.015 \pm 0.02$ & $0.65 \pm 0.99$ & $0.014 \pm 0.02$ \\
\hline SA & $0.83 \pm 1.31$ & $0.018 \pm 0.03$ & $0.60 \pm 0.94$ & $0.012 \pm 0.02$ \\
\hline T & $0.97 \pm 1.30$ & $0.025 \pm 0.03$ & $0.31 \pm 0.54$ & $0.006 \pm 0.01$ \\
\hline TA & $1.00 \pm 1.43$ & $0.027 \pm 0.03$ & $0.36 \pm 0.84$ & $0.008 \pm 0.02$ \\
\hline
\end{tabular}

Values are presented as mean \pm standard deviation; between groups analysis Nv[cap] - Soleus, $F=2,303(p=0.359)$; $E D L, F=2,195$ ( $p=0.061)$; Ratio[cap/fib] - Soleus, $F=2.572(p=0.038) ; E D L, F=1,954$ ( $p=0.101)$.

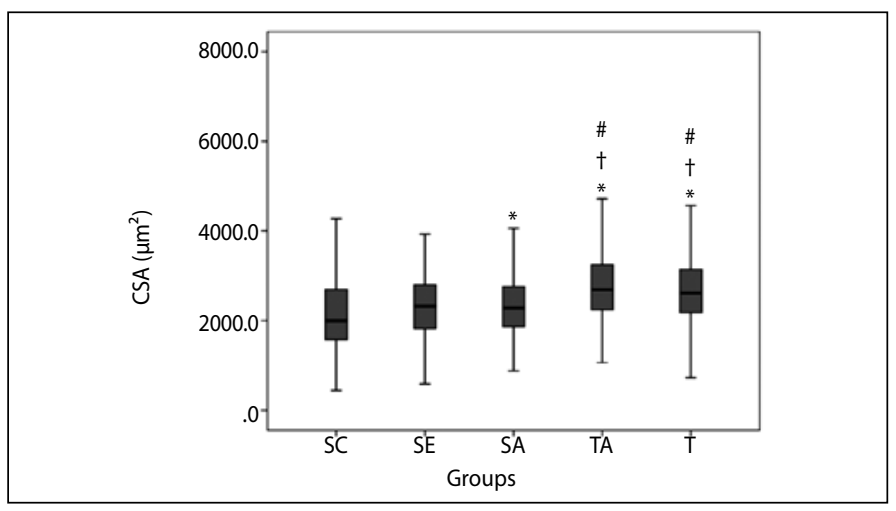

Figure 2. Cross-sectional area of Soleus between groups: Control (SC), Sedentary aged (SE), Aged with Anabolic (SA), Trained (T) and trained with Anabolic (TA). Data are presented by *SC vs SA, T, TA; †SE vs TA, T; \#SA vs SC, T, TA; F $=54.784(p<0,001)$.

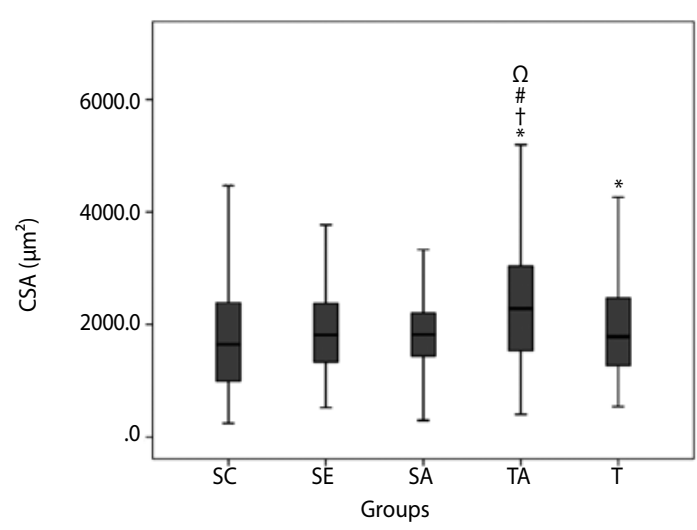

Figure 3. Cross-sectional area of Extensor digitorum longus between groups: Control (SC), Sedentary aged (SE), Aged with Anabolic (SA), Trained (T) and trained with Anabolic (TA). Data are presented by *SC vs TA, T; †SE vs TA; \#SA vs TA; $\Omega$ T vs TA; $F=48.842(p<0,001)$.

and Testosterone application. However, both muscle types hypertrophied after RT and Testosterone use.

Through our work, the stereological model of analysis failed to identify any significant changes in both EDL and SL after anabolic steroid and/or RT. Nevertheless, SL appeared to be more sensitive, increasing the density of capillaries in groups $T$ and $T A$, whereas the EDL muscle presented inversely results. Degens ${ }^{15}$ and Andersen ${ }^{16}$ indicated that capillary supply is determined partly by the muscle size and metabolic profile, and then predominance of muscle fiber type. It is clear that only T and TA demonstrated greater potential for change, although not significant. However, when comparing groups between both muscles, we showed that Soleus muscle presented a higher Vv[cap] compared to ELD. Further analysis, revealed that T and TA also did not interfere on Nv[cap] or ratio[cap/fib].

Measurement of capillary density in different muscle types was main goal in some cross-sectional, longitudinal and training studies in earlier 90 s and 2000s. In a longitudinal study of Frontera et al. ${ }^{17}$, capillary density decreased in Quadriceps femoralis muscle. Chilibeck et al. ${ }^{2}$ and Coggan et al. ${ }^{3}$ found no significant difference in capillary density of Gastrocnemius muscle of young and elderly groups. Corroborating our data, Hagerman et al. ${ }^{18}$ also found no significant difference in capillary density of the Vastus lateralis of elderly who underwent a RT program to voluntary failure. Besides these conflicting data, the amount of work analyzing vascularity of different muscle types is small. Desaki and Nishida ${ }^{19}$ demonstrated that capillaries from EDL, decreased over 24 and 27 months of age. According to another study, capillary can be reduced or even degenerate and/or destroyed during advanced $a g e^{20}$. So far, comparison of our data and the available literature, demonstrated that if skeletal muscle capillarity profile were influenced by aging process, it would just occur at very late ages.

Very few studies investigated the effects of anabolic steroid on capillary volume. Dimauro and colleagues ${ }^{21}$ studied the effects of high intensity short duration swimming training and anabolic steroid treatment on the medial Gastrocnemius muscle of female rats. The authors showed that only swimming training but not anabolic steroid resulted in significant increases in the number of capillaries surrounding type I and lla muscle fibers. Our results demonstrated that neither intervention caused any capillary profile alteration.

Physiological dosages of androgenic anabolic steroids (AAS) may not be sufficient to induce muscle hypertrophy. According to Katznelson et al. ${ }^{22}$, supra-physiological doses of AAS shall have a greater overall effect than therapeutic doses. In addition, skeletal muscle response might varied depending on intervention applied and skeletal muscle type ${ }^{23}$. Here, morphometric study showed that muscular hypertrophy occurred in both muscles, however, differently between muscle and intervention applied. Recently, our group showed that RT and testosterone caused a decrease in numerical density of myocytes (Nv[myo]) per analyzed frame ${ }^{23}$. However, aged group also demonstrated this same phenomenon. Possibly, these facts might be explained by different theories. Aged muscle might decrease it cell number, whereas trained ones increased CSA. At both analysis, it could result in decreased number of myocytes counted on each frame.

Kovacheva et al..$^{24}$ showed that CSA from Gastrocnemius muscle increased in both fast and slow muscle fibers after anabolic steroid administration through suppression of both myostatin levels and stresslike enzyme c-Jun N-terminal kinase (JNK). Further, Kawada et al. ${ }^{25}$ found significant reductions in myostatin content of Gastrocnemius and SL. Despite, it seems clear that hypertrophic response to anabolic steroid is dose-dependent ${ }^{23}$. Perhaps, greater dosages might trigger greater muscle hypertrophy gains and capillarity volume increase.

$\mathrm{RT}$ is great to reduce the rates of muscle loss and increase muscle strength $^{26}$. Animals from T, showed significant increase of SL and EDL CSA. RT is as effective as testosterone to increase myofibers expression of several growth factors and new protein synthesis ${ }^{27}$.

Lambert et al. ${ }^{28}$ demonstrated that RT and anabolic steroid should lead to greater muscle mass increases. Bhasin et al. ${ }^{29}$ and Bhasin et al. ${ }^{30}$ demonstrated that combination of RT and anabolic steroid were more effective to muscle hypertrophy than each intervention alone. This fact is explained by a more potent interaction with Androgen Receptor [AR] after both treatments ${ }^{31}$.

Despite the results presented, our work might be influenced by some limitations, such as: sample number and RT features. Sample number is known to be an important factor, even when dealing with animal research. Perhaps, a larger sample might be necessary to achieve a more robust analysis. Training features, such as intensity and volume, or training with percentage body weight are very important to induce muscular adaptation. Here, we adapted Heyward table to rodent RT. This 
strategy could be insufficient to induce greater results, even knowing that some experimental groups presented significant muscular hypertrophy.

\section{CONCLUSION}

In summary, type of intervention used did not affect any capillarity profile measure, even though muscular hypertrophy. Although, EDL has a tendency to decrease capillary volume over conjugated use of RT and anabolic steroid.

All authors have declared there is not any potential conflict of interests concerning this article.

AUTHORS' CONTRIBUTIONS: Each author contributed individually and significantly to the development of the manuscript. WKN (0000-0002-6881-0208)* trained the animals, analyzed the data and wrote the final manuscript. EFG (0000-0002-9770-8819)* guided the whole process, assisted in the statistical analysis and discussion, and approved the final version of the manuscript. *ORCID (Open Researcher and Contributor ID).

\section{REFERENCES}

1. Harris BA. The influence of endurance and resistance exercise on muscle capillarization in the elderly: a review. Acta Physiol Scand. 2005;185(2):89-97.

2. Chilibeck PD, Paterson DH, Cunningham DA, Taylor AW, Noble EG. Muscle capillarization O2 diffusion distance, and VO2 kinetics in old and young individuals. J Appl Physiol (1985). 1997;82(1):63-9.

3. Coggan AR, Spina RJ, Rogers MA, King DS, Brown M, Nemeth PM, et al. Histochemical and enzymatic characteristics of skeletal muscle in master athletes. J Appl Physiol (1985). 1990;68(5):1896-901.

4. Hudlicka O, Brown M, Egginton S. Angiogenesis in skeletal and cardiac muscle. Physiol Rev. 1992;72(2):369-417.

5. Jakobsson F, Borg K, Edström L. Fibre-type composition, structure and cytoskeletal protein location of fibres in anterior tibial muscle. Comparison between young adults and physically active aged humans. Acta Neuropathol. 1990;80(5):459-68.

6. Bhasin S, Woodhouse L, Storer TW. Proof of the effect of testosterone on skeletal muscle. J Endocrinol. 2001;170(1):27-38

7. Gonçalves L, de Souza RR, Maifrino LB, Caperuto ÉC, Carbone PO, Rodrigues B, et al. Resistance exercise and testosterone treatment alters the proportion of numerical density of capillaries of the left ventricle of aging Wistar rats. Aging Male. 2014;17(4):243-7.

8. Hornberger TA Jr, Farrar RP. Physiological hypertrophy of the FHL muscle following 8 weeks of progressive resistance exercise in the rat. Can J Appl Physiol. 2004;29(1):16-31.

9. Heyward VH. Designing resistance training programs. In: Heyward V. Advanced fitness assessment and exercise prescription 3rd ed. Champaing Illinois: Human Kinetics; 1998. p. 121-44.

10. Chaves DF, Carvalho PC, Lima DB, Nicastro H, Lorenzeti FM, Siqueira-Filho M, et al. Comparative proteomic analysis of the aging soleus and extensor digitorum longus rat muscles using TMT labeling and mass spectrometry. J Proteome Res. 2013;12(10):4532-46

11. Rice KM, Preston DL, Neff D, Norton M, Blough ER. Age-related dystrophin-glycoprotein complex structure and function in the rat extensor digitorum longus and soleus muscle. J Gerontol A Biol Sci Med Sci. 2006;61(11):1119-29.

12. Mandarim-de-Lacerda CA. Stereological tools in biomedical research. An Acad Bras Cienc. 2003;75(4):469-86.

13. Porter MM, Koolage CW, Lexell J. Biopsy sampling requirements for the estimation of muscle capillarization. Muscle Nerve. 2002;26(4):546-8.

14. Hepple RT, Mathieu-Costello O. Estimating the size of the capillary-to-fiber interface in skeletal muscle: a comparison of methods. J Appl Physiol (1985). 2001;91(5):2150-6.

15. Degens H. Age-related changes in the microcirculation of skeletal muscle. Adv Exp Med Biol. 1998;454:343-8.

16. Andersen P. Capillary density in skeletal muscle of man. Acta Physiol Scand. 1975;95(2):203-5.

17. Frontera WR, Hughes VA, Fielding RA, Fiatarone MA, Evans WJ, Roubenoff R. Aging of skeletal muscle: a 12-yr longitudinal study. J Appl Physiol (1985). 2000;88(4):1321-6.
18. Hagerman FC, Walsh SJ, Staron RS, Hikida RS, Gilders RM, Murray TF, et al. Effects of high-intensity resistance training on untrained older men. I. Strength, cardiovascular, and metabolic responses. J Gerontol A Biol Sci Med Sci. 2000;55(7):B336-46.

19. Desaki J, Nishida N. Structural changes of microvessels in the extensor digitorum longus muscle of the aged rat. J Electron Microsc (Tokyo). 2007;56(4):157-62.

20. Desaki J, Oki S, EzakiT. Remodelling of capillary networks around muscle fibres in the extensor digitorum longus muscle of the normal aged rat. J Electron Microsc (Tokyo). 2002;51(3):183-94.

21. Dimauro J, Balnave RJ, Shorey CD. Effects of anabolic steroids and high intensity exercise on rat skeletal muscle fibres and capillarization. A morphometric study. Eur J Appl Physiol Occup Physiol. 1992;64(3):204-12.

22. Katznelson L, Robinson MW, Coyle CL, Lee H, Farrell CE. Effects of modest testosterone supplementation and exercise for 12 weeks on body composition and quality of life in elderly men. Eur J Endocrinol. 2006;155(6):867-75

23. Krause Neto W, Gonçalves L, Nascimento V, Maifrino LBM, de Souza RR, Gama EF. Quantitative morphological analysis revealed muscular hypertrophy in different skeletal muscle types induced by anabolic steroid and resistance training in rats. Aust J Basic Appl Sci. 2013;7(14):591-8.

24. Kovacheva EL, Hikim AP, Shen R, Sinha I, Sinha-Hikim I. Testosterone supplementation reverses sarcopenia in aging through regulation of myostatin, $\mathrm{c}-\mathrm{Jun} \mathrm{NH} 2$-terminal kinase, Notch, and Akt signaling pathways. Endocrinology. 2010;151(2):628-38

25. Kawada S, Okuno M, Ishii N. Testosterone causes decrease in the content of skeletal muscle myostatin. Inter J Sports Health Sci. 2006:4:S44-8.

26. Lynch GS, Schertzer JD, Ryall JG. Therapeutic approaches for muscle wasting disorders. Pharmaco Ther. 2007;113(3):461-87.

27. Snijders T, Verdijk $L B$, van Loon $L$. The impact of sarcopenia and exercise training on skeletal muscle satellite cells. Ageing Res Rev. 2009;8(4):328-38.

28. Lambert CP, Sullivan DH, Freeling SA, Lindquist DM, Evans WJ. Effects of testosterone replacement and/ or resistance exercise on the composition of megestrol acetate stimulated weight gain in elderly men: a randomized controlled trial. J Clin Endocrinol Metab. 2002;87(5):2100-6.

29. Bhasin S, Storer TW, Berman N, Callegari C, Clevenger B, Phillips J, et al. The effects of supraphysiologic doses of testosterone on muscle size and strength in normal men. N Engl J Med. 1996;335(1):1-7.

30. Bhasin S, Storer TW, Javanbakht M, Berman N, Yarasheski KE, Phillips J, et al. Testosterone replacement and resistance exercise in HIV-infected men with weight loss and low testosterone levels. JAMA. 2000;283(6):763-70.

31. Willoughby DS, Taylor L. Effects of sequential bouts of resistance exercise on androgen receptor expression Med Sci Sports Exerc. 2004;36(9):1499-506. 